\title{
CULTURAL PRACTICE AND PROFITABILITY OF RICE-CUM-FISH CULTURE IN A SELECTED AREA OF BANGLADESH
}

\author{
Mohammad Ataur Rahman* | Most. Mahmuda Akter** | Mohammad Shahidul Islam*** \\ *Professor, Department of Agricultural Finance and Banking, Bangladesh Agricultural University, Mymensingh-2202, Bangladesh. \\ ** MS in Agricultural Economics (Finance), Department of Agricultural Finance and Banking, Bangladesh Agricultural University, Mymensingh- \\ 2202, Bangladesh. \\ ***District Fisheries Officer, Phulpur, Mymensingh, Ministry of Fisheries and Livestock Bangladesh.
} DOI: http://doi.org/10.47211/idcij.2021.v08i03.019

\begin{abstract}
The rice-cum-fish culture is an integrated farming system in which, rice is the main enterprise and fish production is taken as additional means to secure extra income. The present study was designed to identify the socioeconomic characteristics of the respondents, cultural practices, profitability and problems and constraints faced by the ricecum-fish farmers. Sherpur district was selected for the study on the basis of extensive cultivation of rice-cum-fish culture. The simple random sampling technique was used for primary data collection from 40 rice-cum-fish farmers through semi-structured interview schedule. Both tabular and functional analyses were used to analyze the collected data. Socioeconomic analysis showed that $37.5 \%$ of the respondents were aged between $41-50$ years, $12.5 \%$ of the respondents were illiterate, $55.7 \%$ respondent's primary occupation was agriculture and $50 \%$ of the household annual income was between Tk. 150000-250000. The study also showed that about $42.5 \%$ of farmers have their own plot, $62.5 \%$ of farmers cultured fish in the paddy field commercially, 55\% farmers were engaged with monoculture, $47.5 \%$ of the respondents collected their fingerling from private hatcheries, monosex tilapia was mainly cultured in the paddy field and $70 \%$ respondents used ready feed for feeding. The profitability analysis showed that per hectare gross return, net return, and gross margin was found to be Tk. 355180, Tk. 230879, Tk. 246179, respectively. Undiscounted benefit-cost ratio was found to be 2.86. The study also identified some of the problems and constraints associated with rice-cum-fish culture. About $97.5 \%$ and $95 \%$ of the respondents replied that lack of good quality seed and fingerling and lack of extension services were their main problems, respectively. Rice-cum-fish farming is the new option for rural people to improve their livelihood. Government and other concern organizations should take necessary steps to improve the rice-cum-fish culture practices.
\end{abstract}

Keywords: Cultural Practice, Profitability, Rice-Cum-Fish Culture, Bangladesh

\section{ABOUT AUTHORS:}

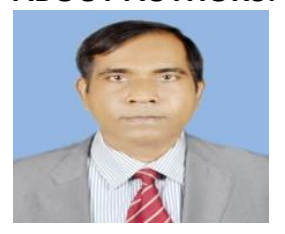

Author, Mohammad Ataur Rahman is currently working as Professor in the Department of Agricultural Finance and Banking in Bangladesh Agricultural University, Mymensingh-2202, Bangladesh.

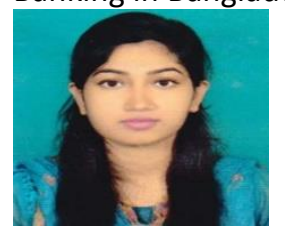

Author, Most. Mahmuda Akter is MS in Agricultural Economics (Finance), Department of Agricultural Finance and Banking, Bangladesh Agricultural University, Mymensingh-2202, Bangladesh.

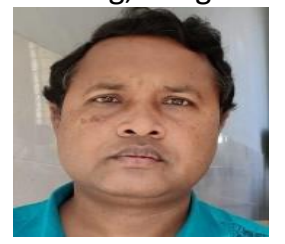

Author, Mohammad Shahidul Islam is District Fisheries Officer in Phulpur, Mymensingh, Ministry of Fisheries and Livestock Bangladesh. 


\section{INTRODUCTION}

Agriculture is the major dominating sector of the country. Agriculture occupies a key position in the overall economic sphere of the country in terms of its contribution to Gross Domestic Product (GDP). About $80 \%$ of its population lives in rural areas, where agriculture is the major occupation and $39.07 \%$ labor force are engaged in agriculture [1]. At present the contribution of agriculture to the total GDP is $17.9 \%$ in which $10.05 \%$ comes from crops, $1.19 \%$ from forestry, $2.41 \%$ from livestock and 3.56\% from fisheries [2].

Rice is the staple food and a major cereal crop of Bangladesh. Basically rice cultivation is the major source of livelihood of the people of Bangladesh. A small parcel of land not only acts as a constraint to profitable investment, but also deprives farmers of access to production inputs, formal credit and other institutional services required for improved agricultural practices.

In an agro-based country like Bangladesh, fisheries sub-sector is one of the most important and promising subsectors having vital contribution towards economic development. The contribution of the fisheries sub-sector was GDP $3.69 \%$ in FY 2018-19 and 3.69\% in FY 2013-14, fisheries sub-sector contributed about $22.6 \%$ to the broader agricultural sector GDP [3]. This sector plays a significant role in meeting the protein demand, earning foreign exchange and socioeconomic development of the rural poor by reducing poverty through employment generation. Over a long history, fish is cultivated in some wet rice fields, either concurrently or rotationally in Asia Region [4]. Rice and fish have been an essential part of life and culture of the people of Bangladesh. Bangladeshi people were popularly referred to as "Macche-Bhate Bangali". Despite the fact that rice is still the staple food and that there is self-sufficiency in production to feed 160 million people [5]. The total area of rice fields in Bangladesh is about 10.14 million hectares which can play an important role in increasing fish production [6]. The potential capacities of these lands and water bodies are not fully utilized, but there exists tremendous scope for integrated aquaculture-agriculture system that is integration of fish with rice production for sustaining and improving productivity as well as profitability of the farms [7]. The notion of fish culture in rice fields originated with a view to ensure better return from rice for farmers through efficient use of scarce land resources.

The introduction of fish rearing with rice farming creates an integrated agro ecological system. Rice is a globally important stable food crop, with a wide distribution and constituting diversified varieties. Rice-cum-fish farming systems constitute a unique agro-landscape across the world, especially in tropical and sub-tropical Asia. The basic principles involved in integrated farming are the utilization of the synergistic effects of integrated farming activities and the full utilization of farm waste. It is based on the concept that "There is no waste" and "Waste is only a misplaced resource which can become a valuable material for another product" [8]. Integration of fish with other animal and crops is the most efficient way of increasing production from per unit area of land. Integration within the farm has been a practical necessity, where farmed fish have been economically and nutritionally important. Integrated aquaculture compliments and improves the overall yield in terms of labor input, efficiency and resource use. The most common forms of integration are those where there is a direct and simple link between activities, such as the use of animal, crop waste as fish feed and fertilizer. Rice-cum-fish is a common practice of integrated farming system in Bangladesh.

There are four basic type of rice, agro-ecosystems: irrigated ecosystems, upland (terraces), lowland rain fed ecosystems and flood-prone (very deep water) ecosystems. Rice-fish culture enhances both rice and fish production, but production is high at low-medium intensities although the fish diversity is mostly in traditional and low intensity systems. Rice-cum-fish farming is innovative and adapting to changes in rice farming. There are basically two types of rice-fish or rice-cum- fish systems in Asia, concurrent (or mixed) and rotational, each with four intensities of production: traditional, low, moderate, and high intensity with cultured fish [9].

The rice-fish system provides multifunctional goods and services: food security (rice and fish production); nutrition and income generation (consumption and sale of fish); conservation of biodiversity (fish and associated species help to use less pesticides); pest regulation (fish feed on insects and cleans pathogen with water); pollination (fish hits rice plants and helps the rice pollination); carbon and nutrient cycles (fish reduces residues of plants and recycle nutrient by excrement, Azolla on the surface of water and also fixes nitrogen) and soil and water conservation and restoration (rice fields retain water and harvest soil nutrient from the natural streams and canals).

In a country like Bangladesh where land is scarce, efforts should be made to increase food production through integration of various production systems like fish culture in rice fields for efficient utilization of scarce resources and maximization of diversified production. The fish culture in rice fields is an innovative farming system in which, rice is the main enterprise and fish production is taken as additional means to secure extra income. Therefore, 
huge rice cultivated area, especially in medium to medium-high land, where the water holding capacity is high can be developed for fish culture in rice fields following a simple management system. Rice-cum-fish ecosystem is giving an additional production from rice fields and at the same time fishes eat up harmful insects, egg and larvae from rice fields, leading to more production and less use of insecticide. Moreover, excrete of fishes becomes a potential source of organic fertilizer for rice plant nutrition, and fish movement in water diffuses more oxygen for better nutrient uptake of plants. So, this system is ecologically sound and environmentally friendly. On the other hand, poor families having small rice fields fit for rice-fish culture cannot utilize their limited resource for good harvest due to lack of financial capacity and technical know-how. This type of technology, if disseminated through training followed by credit assistance, might be the source of additional income and family nutrition. Culturing fish in rice fields through improved technology will help the poor farmers to increase their income and ensure food security in lean periods.

Although this practice has gained remarkable popularity, the people do not adequately know the economic consequences of this practice and solution of the problems which they face. On the basis these situations, answers of the following research questions tried to find out through this study. What are the socioeconomic conditions of the rice-cum-fish farmers? Is this technology profitable, what are the cultural practices they follow? And what are the problems and constraints they face?

The study will determine profitability of raising fish in the rice fields by the farmers. Thus, it is believed that the proposed study will contribute significantly in adding new knowledge in the field of agricultural production policy. The study deals with some hitherto uncovered issues and hence may be considered important both for farmers and policy makers in agriculture. The objectives of the study were to assess the socioeconomic conditions, profitability, cultural practices and problems and constraints of rice-cum-fish culture.

\section{MATERIALS AND METHODS}

Both primary and secondary data were collected for this research. Sherpur district in Bangladesh was purposively selected for this study; because of many rice-cum-fish fields are available there. The study was carried out mainly through a survey of 40 rice-cum-fish farmers. Multi-stage sampling procedure was used to select households for data collection. A semi-structured interview schedule was used to obtain farm and household level information. A number of tables were prepared for keeping in view the aims and objectives of the study. Tabular and statistical analysis techniques were used to achieve the objectives.

\section{Functional Analysis}

Gross Return

Gross return (GR) was calculated by multiplying the total volume of output of an enterprise by the average price in the harvesting period [10]. The following equation was used to estimate GR.

$\mathrm{GR}_{\mathrm{i}}=\sum_{i=1}^{n} Q_{i} P_{i}$

Where,

$\mathrm{GR}_{\mathrm{i}}=$ Gross return from $\mathrm{i}^{\text {th }}$ product $(\mathrm{Tk} . / \mathrm{ha})$;

$\mathrm{Q}_{\mathrm{i}}=$ Quantity of $\mathrm{i}^{\text {th }}$ product $(\mathrm{Kg} / \mathrm{ha})$;

$\mathrm{P}_{\mathrm{i}}=$ Average price of the $\mathrm{i}^{\text {th }}$ product $(\mathrm{Tk} . / \mathrm{Kg})$;

$\mathrm{i}=1,2,3, \ldots \ldots \ldots \ldots . . . ., \mathrm{n}$.

Gross Margin

Gross margin has given an estimate of the difference between total return and variable costs.

That is

$\mathrm{GM}=\mathrm{TR}-\mathrm{VC}$

Where,

$\mathrm{GM}=$ Gross margin

$\mathrm{TR}=$ Total return

VC $=$ Variable costs

Net Return

The net return analysis considered fixed costs; cost of land rent, interest on operating capital, etc. Net return was calculated by deducting all cost (variable and fixed) from gross return. To determine the net return of rice-cum fish production the following equation was used in the present study: 
$\pi=P_{y} Y-\sum_{i=1}^{n}\left(P_{x i} X\right)-T F C$

Where,

$\pi=$ Net return (Tk./ha);

$\mathrm{Py}_{\mathrm{y}}=$ per unit price of the product $(\mathrm{Tk} . / \mathrm{kg})$;

$\mathrm{Y}=$ Quantity of the production per hectare $(\mathrm{Kg})$;

$P_{x i}=$ Per unit price of $i^{\text {th }}$ inputs (Tk.);

$X_{i}=$ Quantity of the $i^{\text {th }}$ inputs per hectare $(\mathrm{kg})$;

TFC $=$ Total fixed cost (Tk.);

$i=1,2,3 \ldots \ldots \ldots \ldots \ldots . ., n$ (number of inputs).

\section{RESULTS AND DISCUSSION}

\section{Socioeconomic characteristics of the sample households}

The socioeconomic status of a household was analyzed considering age, education level, occupation and income level of the respondents. Age of farmers has an influence on the production and in the better management of the farming system. Some researchers think that the older farmers are more experienced and more efficient in resource use. Other researchers comment that younger farmers are eager to adopt improved technology than older.

Table1. Socioeconomic characteristics of the households

\begin{tabular}{|c|c|c|}
\hline Age Group & No. of Respondent & Percentage \\
\hline Below-30 & 6 & 15 \\
\hline $31-40$ & 14 & 35 \\
\hline $41-50$ & 15 & 37.5 \\
\hline Above 50 & 5 & 12.5 \\
\hline Total & 40 & 100 \\
\hline \multicolumn{3}{|c|}{ Categories according to education level } \\
\hline Illiterate rate & 5 & 12.5 \\
\hline Can sign only & 2 & 5 \\
\hline Primary education & 6 & 15 \\
\hline Secondary Education & 16 & 40 \\
\hline Above Secondary & 11 & 27.5 \\
\hline Total & 40 & 100 \\
\hline \multicolumn{3}{|l|}{ Primary occupation } \\
\hline Agriculture & 23 & 57.5 \\
\hline Small business & 7 & 17.5 \\
\hline Service & 4 & 10 \\
\hline Fishery & 6 & 15 \\
\hline Total & 40 & 100 \\
\hline \multicolumn{3}{|c|}{ Annual income of the households (Tk.) } \\
\hline Below 150000 & 5 & 12.5 \\
\hline $150000-250000$ & 20 & 50.0 \\
\hline $250001-350000$ & 8 & 20 \\
\hline Above 350000 & 7 & 17.5 \\
\hline Total & 40 & 100 \\
\hline
\end{tabular}

Source: Field Survey, 2019

In the present study, all categories of farmers of the study area were classified into different age groups as presented in Table 1. The rice-cum-fish farmers were classified into four groups: up to 30 years, 31- 40 years, 41 50 years and above 50 . Out of the total sample farmers $15.0 \%$ belonged to the age group of up to 30 years, $35.0 \%$ belonged to the age group of up to $31-40$ years, $37.5 \%$ belonged to the age group of up to $41-50$ years and $12.5 \%$ fell into the age group of above 50. It is evident from the Table 1 that most of the farmers were middle aged in the study area. Every rice-cum fish farmer will have some academic background because present day, type of fish culture is based on scientific method and the producers need to have some knowledge on improved fish culture 


\section{ARTICLES}

techniques. On the basis of educational qualification, the educational status of respondent farmers has been categorized into six categories. It is evident from Table 1 that $12.5 \%$ farmers were illiterate, $15 \%$ farmers had primary education, $40 \%$ had completed secondary education and only $27.5 \%$ farmers had above secondary level education.

Agriculture is the main occupation of most of the farmers in the study area. Besides agriculture, some farmers were engaged in other occupations like, small business, services and fishery. Table 1 shows that $57.5 \%$ rice-cumfish farmers were engaged in agriculture while $17.5 \%$ were engaged in small business, $10 \%$ in service and $15 \%$ in the fishery as their main occupation. In the study, it was found that $12.5 \%$ of the farmers were included in annual income level of below Tk.150000, 50\% of farmers were Tk. $150000-250000,20 \%$ of farmers were Tk. 250001$350000,17.5 \%$ of farmers were of above Tk. 350000.

\section{Cultural practices of fish in the paddy field}

To know the cultural practices of rice-cum-fish culture in the study area is very important for policy recommendations. The cultural practices include: plot ownership pattern, category of plot, the type of culture practices, and source of fingerlings, feeds and feeding process. The plot ownership pattern is categorized by whether the plot is owned by single, multiple or leased. Table 2 shows that $42.5 \%$ of farmers have their own plot, $32.5 \%$ of farmers practice their culture as a multiple ownership pattern, and finally $25 \%$ of the sample farmers have to do their rice cum fish practice in a leased plot.

Table 2. Cultural practices of rice-cum-fish

\begin{tabular}{|c|c|c|}
\hline Plot ownership pattern & No. of Respondent & Percentage \\
\hline Single & 17 & 42.5 \\
\hline Multiple & 13 & 32.5 \\
\hline Leased plot & 10 & 25 \\
\hline Total & 40 & 100 \\
\hline \multicolumn{3}{|l|}{ Category of plot } \\
\hline Homestead & 15 & 37.5 \\
\hline Commercial & 25 & 62.5 \\
\hline Total & 40 & 100 \\
\hline \multicolumn{3}{|l|}{ Type of cultured practiced } \\
\hline Monoculture & 22 & 55 \\
\hline Polyculture & 18 & 45 \\
\hline Total & 40 & 100 \\
\hline \multicolumn{3}{|l|}{ Source of Fingerling } \\
\hline Natural & 3 & 7.5 \\
\hline Private hatchery & 19 & 47.5 \\
\hline Govt. hatchery & 18 & 45 \\
\hline Total & 40 & 100 \\
\hline \multicolumn{3}{|l|}{ Cultured species } \\
\hline Monosex tilapia & 40 & 100 \\
\hline Silver carp & 36 & 90 \\
\hline Catla & 35 & 87.5 \\
\hline Rui & 34 & 85 \\
\hline Grass carp & 37 & 92.5 \\
\hline Common carp & 34 & 85 \\
\hline Mrigel & 39 & 97.5 \\
\hline \multicolumn{3}{|l|}{ Feed category } \\
\hline Mustard oil cake & 11 & 27.5 \\
\hline Rice burn & 9 & 22.5 \\
\hline Fish meal & 12 & 17.14 \\
\hline Aquatic weed & 12 & 17.14 \\
\hline Others (Ready feed) & 28 & 70 \\
\hline
\end{tabular}

Source: Field Survey, 2019 
The plot ownership pattern has an impact on profitability of rice cum fish culture. As profits are to be distributed among the partners of multiple ownership pattern, on the other hand, those who practice rice cum fish culture in a leased land have to pay a leased cost which is not required in a single ownership pattern.

We can know the purpose of fish cultured in the paddy field, whether only used for family consumption for commercial purpose from category of plot; homestead or commercial. Table 2 shows that only $37.5 \%$ farmers cultured fish in the paddy field for household consumption and $62.5 \%$ cultured fish in the paddy field commercially.

Monoculture is the agricultural practice of producing or growing a single crop, plant, or livestock species, variety, or breed in a field or farming system at a time. Polyculture, where more than one fish species are cultured in the same time, is the alternative to monoculture. Table 2 shows that about $55 \%$ of respondents were engaged in the monoculture type of culture and about 45 percent of them were engaged in a polyculture type of culture.

It is important to know about the source of fry or fingerlings which were used in fish culture in a paddy field. The sources were natural, private hatchery and government hatchery. Table 2 shows that $47.5 \%, 45 \%$ and $7.5 \%$ of the respondents collected their fingerling from private hatchery, govt. hatchery, and natural sources, respectively.

The fish species which could be cultured in the paddy fields must be capable of tolerating shallow water (>15 cm depth), high temperature (up to 35 degree Celsius), low dissolved oxygen and high turbidity. Species mainly Labeo rohita, Catla catla, Oreochromis mossambicus, Anabas testidineus, Clarias batrachus, Clarias macrocephalus, channa maruilius, Heteropneustes fossils, Chanos chanos, and Lates calcarifer have been widely cultured in the paddy fields.

Although small scale fish farming in rice fields is an extensive aquaculture system that relies on the natural food (phytoplankton, zooplankton, peripthyton, benthos), supplemental feeds are used by most of the respondents. Feeding of the stocked fish in the paddy field started immediately after stocking at established feeding spots. The fish were fed once in a day. The desired required proximate composition and quantity of the feed ingredients were must be given to the fingerlings at proper scheduled period. The fishes are provided with supplementary food consisting of rice bran and groundnut oil cake in the ratio 1.1 at $5 \%$ body weight of fishes. Table 2 shows that $70 \%$ of the respondents used ready feed for feeding purpose. And the rest of the farmers used rice burn, fish meal and aquatic weed combined for feeding purpose.

\section{Profitability rice-cum-fish culture}

The main purpose of this part is to estimate the costs and returns of rice-cum-fish culture. For calculating the costs and returns of rice-cum-fish culture, the cost items were classified into two groups, (i) Variable cost and (ii) Fixed Cost. Variable cost included the cost of all variable factors like human labor, power tiller, seedling, fingerling, fertilizer, power tiller, irrigation, feed, ditch excavation, interest on operating capital interest on operating capital. On the other hand, fixed cost was the land use cost. Table 3 shows the total cost of rice-cum-fish culture.

Table 3. Per hectare total cost of rice-cum-fish culture

\begin{tabular}{|l|c|c|c|c|}
\hline Items & Units & Quantity & Price/ Unit & Cost (Tk.) \\
\hline A. Variable Cost & & & & \\
\hline Human labor & Man-days & 110 & 300.00 & 33000 \\
\hline Power tiller cost & Tk. & - & - & 7750 \\
\hline Seedlings & $\mathrm{Kg}$ & 65 & 100.00 & 6500 \\
\hline Fingerlings & $\mathrm{No}$. & 3036 & 5.00 & 15180 \\
\hline Fertilizer & & & & \\
Urea & $\mathrm{Kg}$ & 146 & 17 & 2482 \\
TSP & $\mathrm{Kg}$ & 97 & 34 & 3298 \\
MP & $\mathrm{Kg}$ & 49 & 15 & 735 \\
\hline Cow dung & $\mathrm{Kg}$ & 4640 & .50 & 2320 \\
\hline Irrigation cost & $\mathrm{Tk}$. & - & - & 2300 \\
\hline Feed cost & $\mathrm{Tk}$. & - & - & 13350 \\
\hline Oil cake & $\mathrm{Tk}$. & & & 3300 \\
\hline Rice barn & $\mathrm{Tk}$. & & & 3400 \\
\hline Fish meal & $\mathrm{Tk}$. & & & 3050 \\
\hline Ready feed & $\mathrm{Tk}$. & & & 3600 \\
\hline Ditch excavation & $\mathrm{Tk}$ & & - & 7200 \\
\hline
\end{tabular}




\section{ARTICLES}

\begin{tabular}{|l|c|c|c|c|}
\hline Lime & $\mathrm{Kg}$ & 46 & 25 & 1150 \\
\hline Interest on Capital & $\mathrm{Tk}$ & - & $14 \%$ & 3686 \\
\hline Total variable cost & & & & $\mathbf{1 0 9 0 0 1}$ \\
\hline B. Fixed Cost & & & & \\
\hline Land use cost & Tk. & - & - & 15300 \\
\hline Total cost(A+B) & Tk. & & & $\mathbf{1 2 4 3 0 1}$ \\
\hline
\end{tabular}

Source: Field Survey, 2019

Gross Return

Gross return is the money value of total output. In this study, the gross return was calculated by summing up all the returns earned from selling rice, fish and rice straw. Per hectare gross return was calculated by multiplying the total amount of products and by products with the farm- gate price. Total gross return from rice production was Tk. 129100 while the fish production was Tk.226080 and by product was Tk. 20000. Per hectare gross return from rice-cum-fish production was Tk. 355180 (Table 4).

Table 4. Per hectare gross return from rice-cum-fish culture

\begin{tabular}{|l|c|c|c|c|c|}
\hline \multirow{2}{*}{ Production } & \multicolumn{3}{|c|}{ Main product } & \multirow{2}{*}{$\begin{array}{c}\text { Value of by } \\
\text { product (Tk.) }\end{array}$} & \multirow{2}{*}{ Gross return (Tk.) } \\
\cline { 2 - 6 } & $\begin{array}{c}\text { Qty } \\
\text { (kg) }\end{array}$ & $\begin{array}{c}\text { Price } \\
\text { (Tk.kg) }\end{array}$ & Value (Tk.) & 20000 & 129100 \\
\hline Yield of rice & 5455 & 20 & 109100 & & 226080 \\
\hline Yield of fish & 2826 & 80 & 226080 & & 355180 \\
\hline Total & & & & & \\
\hline
\end{tabular}

Source: Field Survey, 2019

\section{Net Return}

In general net return is termed as entrepreneur's income. The net return is the difference between gross return and total costs. Table 5 reveals that per hectare net return from production of rice-cum-fish was Tk. 230879 which indicates that rice-cum-fish culture is profitable business.

Table 5. Per hectare net return of rice-cum-fish culture

\begin{tabular}{|l|c|}
\hline \multicolumn{1}{|c|}{ Particulars } & Total value (Tk.) \\
\hline A. Gross Return & 355180 \\
\hline B. Variable cost & 109001 \\
\hline C. Total Cost & 124301 \\
\hline D. Gross Margin(A-B) & 246179 \\
\hline E. Net Return(A-C) & 230879 \\
\hline F. BCR(Undiscounted )(A/C) & 2.86 \\
\hline
\end{tabular}

Source: Field Survey, 2019

Problems and constraints of rice-cum-fish culture

Farmers were facing many problems and constraints in integrated rice-cum-fish culture. The problems were classified into three categories: a) Economic problems b) Technical problems and c) Social problems. Table 6 shows some problems and constraints of rice-cum-fish culture. 


\section{ARTICLES}

Table 6. Problems and constraints in rice-cum-fish culture

\begin{tabular}{|c|c|c|c|c|c|}
\hline Problems and constraints & \multicolumn{5}{|c|}{ No. of times problems was ranked } \\
\hline a) Economic problems & First & Second & Third & Fourth & Total $(n=40)$ \\
\hline i. Lack of sufficient fund & 7 & 9 & 4 & 6 & $26(65)$ \\
\hline ii. High price of input & 8 & 7 & 5 & 8 & $28(70)$ \\
\hline iii. Low price of output & 9 & 6 & 4 & 7 & $26(65)$ \\
\hline b) Technical problems & & & & & \\
\hline $\begin{array}{l}\text { i. Lack of scientific knowledge and } \\
\text { technology }\end{array}$ & 12 & 10 & 7 & 6 & $35(87.5)$ \\
\hline ii. Lack of good quality seed and fingerling & 10 & 11 & 9 & 10 & $39(97.5)$ \\
\hline iii. Lack of extension services & 16 & 9 & 6 & 7 & $38(95)$ \\
\hline iv. Attack of disease and pest & 12 & 14 & 7 & 5 & $38(95)$ \\
\hline c) Social problems & & & & & \\
\hline i. Problems of theft & 0 & 0 & 3 & 4 & $7(17.5)$ \\
\hline
\end{tabular}

Source: Field Survey, 2019 (Figures within parentheses indicate percentage of total)

Table 6 shows that in the study area, lack of quality seeds and fingerlings was one of the main problems for ricecum-fish culture. About $97.5 \%$ rice-cum-fish farmers complained about absence of quality seeds and fingerlings. Integrated rice-cum-fish culture is a new concept of farming systems. So, the farmers of rice-cum-fish culture need sufficient service from extension agencies. About $95 \%$ rice-cum-fish farmers reported this type of problem and about $95 \%$ of rice-cum-fish farmers reported that their rice and fish were attacked by diseases and pests.

\section{CONCLUSION}

Rice-cum-fish farming is profitable agribusiness in the study area. If modern inputs and production technology can be made available to farmers in time, yield and production of rice-fish may be increased which can help the farmers to increase income and improve livelihood conditions. The rice-cum-fish farming can help in improving the nutritional status of the rural people. Rice-cum-fish farmers are facing some problems and constraints. Different organizations should take necessary action to mitigate these problems and constraints. With a view to improving rice-cum-fish culture, the application of scientific method in rice-cum-fish farming should be ensured, modern practices need to be popularized among the farmers and extension and training program should be fostered in the study area.

\section{CONFLICT OF INTEREST}

The authors declare no conflicts of interest in this paper. 


\section{ARTICLES}

\section{REFERENCES}

1. Statistical Yearbook of Bangladesh, Bangladesh Bureau of Statistics, Ministry of Planning, Government of the People's Republic of Bangladesh, Dhaka.2017.

2. Statistical Yearbook of Bangladesh, Bangladesh Bureau of Statistics, Ministry of Planning, Government of the People's Republic of Bangladesh, Dhaka. 2018.

3. Bangladesh Economic Review, Ministry of Finance, Government of the People's Republic of Bangladesh, Dhaka. 2018.

4. Qingwen M, Yehong S, Schoubroeck VF, Luohui L, Cruz MJD. The GIAHS-Rice-Fish Culture: China Project Framework. Resources Science 31(1) 10-20.2009.

5. Statistical Yearbook of Bangladesh, Bangladesh Bureau of Statistics, Ministry of Planning, Government of the People's Republic of Bangladesh, Dhaka.2012.

6. Haroon and Pittman. Rice-fish culture: Feeding growth and yield of two size classes of Puntlusgonlonotus Bleeker and Oreochromism sp. In Bangladesh, Institute of Fisheries and Mariner, Biology University of Bergen; Norway. 1997.

7. Ali $\mathrm{MH}$, Miah $\mathrm{NI}$, Nur-E-elahi M. Increasing farm income by introducing fish culture in deep water rice environment. Bangladesh Journal of Fisheries Research, vol. 2 pp.119-126.2002.

8. FAO. China: Recycling of Organic Waste in Agriculture, FAO. Soil Bulletin 40. 1977.

9. Hossain SM, Altaf Ali MM, Dewan S, Islam MS. Rice-Fish Culture. An Adaptable Technology for Bangladesh. Journal of Extension Education 134(1) 40-62.2011.

10. Dillion, J.L. and Hardaker, J.B. Farm Management Research for Small Farmers Development. Food and Agricultural Organization of the United Nations, Rome, Italy.1993. 